\section{TECHNICAL WRITING}

The Presentation of Technical Information

Based on four Public Lectures given at University College, London. By Prof. Reginald O. Kapp. Pp. xi+147. (London: Constable and Co., Ltd., 1948.) 6s. net.

CINCE the lectures on which this book is based $\checkmark$ were delivered in April and May of 1947, the publication of Sir Ermest Gowers" "Plain Words" has stolen some of Prof. Kapp's thunder. There is some common ground in the two books, but Prof. Kapp is concerned with the presentation of technical information and deals with the choice and use of words only so far as they contribute to that purpose : whether or not technical terms, words are to be chosen deliberately so as to serve the technical ideal of fitness for the purpose. That is the ideal which is in Prof. Kapp's mind throughout, just as it dominated Prof. J. R. Nelson's "Writing the Technical Report", a second edition of which appeared last year. Prof. Kapp insists that the presentation of technical information demands the use of what he terms functional English-language in which words are chosen and sentences constructed so as to express the writer's meaning clearly and without ambiguity, and are as appropriate to his purpose as the units selected and used by the designer of an engineering construction. Functional English, he claims, presents facts and ideas simply and logically, but jargon is eschewed by him as firmly as by Sir Ernest Gowers or by Quiller-Couch in a lecture that few scientific writers appear to have discovered.

In his 150 pages, Prof. Kapp includes much that should help the technical or scientific writer to select the words most appropriate for his paper, report or book, and which will best assist the reader —or hearer, for Prof. Kapp is concerned with spoken as well as written exposition-to understand his meaning. Primarily, it is the postgraduate student to whom the book is addressed, but it should be equally welcomed by other students at an earlier stage, though Prof. Kapp provides no ready-made guide or model to be copied. The book is a challenge to real thinking about the task of presentation.

The expositor's first task before he even begins to select his material is to be quite clear in his own mind as to the purpose for which the information to be supplied is required and the reader or audience for whom it is intended. Unless we know the exact purpose to be served we cannot choose the appropriate tools for the task. No commoner error is made, however, in presentation than neglect to decide on that purpose or on the reader to be addressed. By apposite examples, Prof. Kapp illustrates a number of simple rules, observance of which will enable the scientific man to present the results of his investigations in much more readable and therefore effective form. Moreover, Prof. Kapp does this, too, by stimulating thought as well as by pertinent comments on prevalent use and abuse of words, and his book is admirably designed to meet a need voiced at the Royal Society Scientific Information Conference as well as in an ever-growing volume of books and papers.

Prof. Kapp's own book is original in its approach, and his treatment of the theme is clear, vigorous and searching. The book may justly be preferred to some of its more voluminous predecessors, but its merits can scarcely justify the virtual ignoring of all other publications on the subject; and some of his readers might well be grateful for references to other books or papers in which they could pursue their study of a subject Prof. Kapp illuminates but scarcely ex. hausts. He refers, indeed, but vaguely to a paper on the subject in the Journal of the Institution of Electrical Engineers since published by that Institution with others under the title "The Presentation of Engineering Evidence", and apart from the considerable number of books, some indeed of unequal value, concerned with the writing of reports or scientific papers, he gives his readers no indication of the existence of useful and entertaining literature on the handling of words themselves whether for technical or general purposes.

R. BRIGHTMAN

\section{INDEX KEWENSIS}

\section{Index Kewensis Plantarum Phanerogamarum}

Supplementum Decimum: Nomina et Synonyma Omnium Generum et Specierum ab initio Anni 1936 usque ad finem Anni 1940 nonnulla etiam antea edita complectens. Ductu et consilio A. W. Hill (obiit 1941) et E. J. Salisbury. Pp. iii + 251. (Oxford: Clarendon Press; London: Oxford University Press, 1947.) 84s, net.

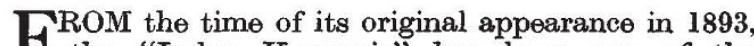
I the "Index Kewensis" has been one of the monumental works in the literature of systematic botany, and the publication of Supplements at regular intervals has always marked a notable stage in the records of plant taxonomy. The appearance of the tenth Supplement is no exception, and although on this occasion there has been inevitable delay in its production, it will none the less receive a warm welcome from botanists throughout the world. To the authorities at Kew every botanical institute must feel indebted for the continuation of an indispensable work of reference.

The present volume covers the five-year period 1936-40, and in its general plan it is similar to previous Supplements. Each page carries three columns, and generic names are arranged alphabetically, as also the specific names under each genus. Some idea of the immense amount of work involved in the preparation of an index of this kind may be obtained from the fact that each of its 251 pages deals with about 105 specific names. This gives an indication also of the contribution which has been made to the systematic study of Phanerogams in the period under review. Not only have large numbers of new species been described, but also numerous new genera have been established, notably in the families Cactaceæ, Compositæ, Gramineæ, and Rubiaceæ. The delimitation of genera in these and other families not infrequently presents considerable difficulty, and it is not surprising that some of the new generic names which appear in the Supplement are due to the elevation of previously recognized sub-genera.

As would be expected, the species which have been described as new to science are distributed among many genera; but the additions to certain of them, such as Carex, Hieracium, Peperomia, Piper, Rubus, Quercus and Salix, are conspicuous by their number. The pages of the Supplement as a whole, however, are testimony to the amount of systematic work which was achieved before the War brought botanical exploration temporarily to a standstill, and they give 